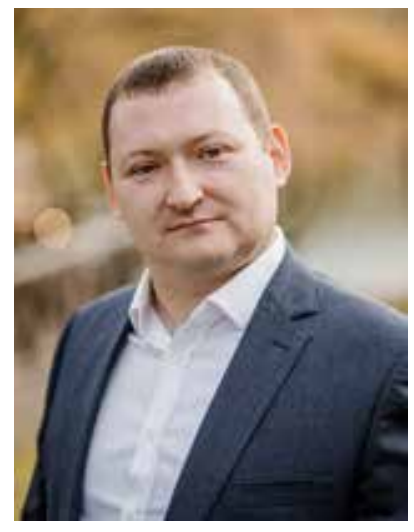

\title{
Володимир Фігурський,
}

кандихат юридичних наук, Аоцент,

Аоцент кафедри кримінального процесу

і криміналістики

^ьвівського національного університету

імені Івана Франка

ORCID: 0000-0002-5329-8985

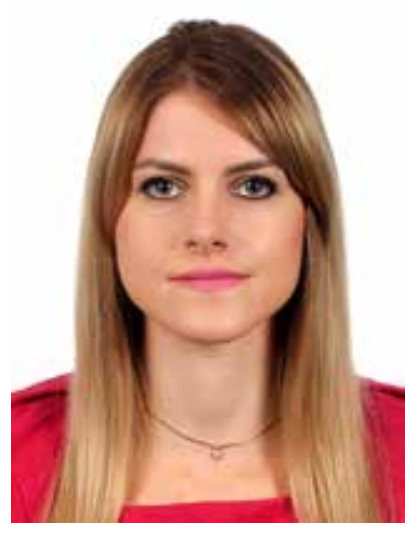

Роксолана Юрків,

аспірантка кафеєри кримінального процесу

і криміналістики

Аьвівського національного університету

імені Івана Франка

ORCID: 0000-0001-9046-8464

https://doi.org/10.32782/2306-9082/2021-41-17

УДК 343.98

\section{Процесуальні дї̈ початкового етапу розслідування підкупу медичних працівників}

Серед кримінальних правопорушень у сфері охорони здоров'я особливе занепокоєння викликають корупційні правопорушення. 3 огляду на це органи правопорядку особливу увагу приділяють протидії протиправній діяльності медичних працівників, виявленню та припиненню їхніх корумпованих діянь. Така протидія здійснюється, серед іншого, шляхом здійснення досудового розслідування загалом і проведення процесуальних дій зокрема.
Проблематика

проведення процесуальних дій у кримінальних провадженнях про одержання неправомірної вигоди грунтовно висвітлена у роботах Ю.О. Андрейка, В.П. Бахіна, І.С. Башмакова, Р.С. Бєлкіна, В.А. Журавля, Ю.П. Гармаєва, Н.А. Жерж, Н.В. Кимлик, Р.В. Кимлика, В.В. Крюкова, С.П. Кушніренка, Я.Є. Мишкова, С.В. Олійника, T.T. Хачатуряна, C.C. Чернявського, B.М. Шевчука, В.Ю. Шепітька та інших дослідників. 
Водночас у наукових працях цих учених не досліджено проведення процесуальних дій у кримінальних провадженнях про підкуп медичних працівників. У зв'язку з цим підлягає з'ясуванню проблема алгоритмізації слідчих (розшукових) та інших процесуальних дій на початковому етапі розслідування кримінальних правопорушень, передбачених ст. ст. 354 , $368^{3}$ та $368^{4}$ КК України. Потребують вивчення й особливості проведення допиту, затримання, огляду, освідування, обшуку на початковому етапі розслідування підкупу медичних працівників. Зазначене зумовлює актуальність теми цієї статті, ïï теоретичне та практичне значення.

Метою статті $\epsilon$ дослідження процесуальних дій початкового етапу розслідування підкупу медичних працівників.

Система та черговість процесуальних дій початкового етапу розслідування підкупу медичних працівників залежить від конкретної слідчої ситуації, що склалася у кримінальному провадженні. Аналіз правозастосовної практики дає можливість констатувати, що типовими слідчими ситуаціями можуть бути: а) заява заінтересованої особи про підкуп медичного працівника, що готується; б) заява заінтересованої особи про факт підкупу медичного працівника; в) відомості про факт підкупу медичного працівника чи підкуп, що готується, отримані від органу, що проводить оперативно-розшукову діяльність; г) відомості про факт підкупу медичного працівника чи підкуп, що готується, одержані слідчим внаслідок розслідування інших кримінальних проваджень.

На початковому етапі розслідування підкупу медичних працівників проводять чимало процесуальних дій. Знання криміналістичних прийомів, уміння їх застосувати у практичній діяльності дає можливість слідчому своєчасно та ефективно здійснювати досудове слідство.

Водночас потребує уточнення твердження, що більшість кримінальних правопорушень, пов'язаних із отриманням неправомірної вигоди, документуються саме в рамках кримінального провадження за наслідками проведення негласних слідчих (розшукових) дій [1, с. 226].

Розділами XV та XVII Особливої частини КК України передбачені кримінальні правопорушення, пов'язані 3 підкупом, - ст. 354 (Підкуп працівника підприємства, установи чи організації), $368^{3}$ (Підкуп службової особи юридичної особи приватного права незалежно від організаційно-правової форми) та $368^{4}$ (Підкуп особи, яка надає публічні послуги), суб'єктами яких можуть бути й медичні працівники. Лише кримінальні правопорушення, визначені у ч. 4 ст. ст. $368^{3}$, $368^{4}$ КК України, належать до категорії тяжких. Стосовно інших кримінальних правопорушень про підкуп медичних працівників, що є предметом цього дослідження (ст. 354, чч. 1-3 ст. 3683, чч. 1-3 ст. $368^{4}$ КК України), можуть бути проведені лише такі негласні слідчі (розшукові) дії, як зняття інформації з електронних інформаційних систем або їх частин, доступ до яких не обмежується іï власником, володільцем або утримувачем чи не пов'язаний 3 подоланням системи логічного захисту, установлення місцезнаходженнярадіоелектронногозасобу.

Наведений висновок підтверджується таким прикладом із правозастосовної практики.

Вироком суду першої інстанції лікар-акушер-гінеколог ОСОБА_4 визнаний невинуватим у пред'явленому обвинуваченні у вчиненні кримінального правопорушення, передбаченого ч. 3 ст. 354 КК України, та виправданий на підставі п. 1 ч. 1 ст. 373 КПК України у зв’язку 
3 недоведеністю вчинення вказаного кримінального правопорушення.

Як вбачається 3 витягу 3 кримінального провадження № 420152200800000095, який міститься в матеріалах кримінального провадження та досліджений судом як процесуальний документ, на підставі заяви ОСОБА_2 про вимагання у нього коштів у розмірі 10000 грн, 17 серпня 2015 р. до ЄРДР внесено відомості за правовою кваліфікацією ч. 3 ст. 354 КК України.

Водночас у матеріалах кримінального провадження міститься постанова в.о. прокурора м. Харкова від 17 серпня 2015 р. про визначення підслідності та постанова прокурора Бєлоусової К. від 17 серпня 2015 р. про визначення підслідності вказаного кримінального провадження СВ Київському РВ ХМУ ГУМВС України в Харківській області за правовою кваліфікацією - ч. 3 ст. 368 КК України, доручення начальника СВ Київського РВ ХМУ ГУМВС України в Харківській області ОСОБА 13 № 61/95 від 17 серпня 2015 р. в.о. слідчого Чуніка Д.М. про проведення розслідування кримінального провадження № 420152204480000095 від 17 серпня 2015 р. за ознаками ч. 3 ст. 354 КК України, та повідомлення слідчого СВ Київського РВ ХМУ ГУМВС України в Харківській області ОСОБА_14 на адресу прокурора Київського району м. Харкова про початок досудового розслідування від 17 серпня 2015 р., де зазначено, що 17 серпня 2015 р. за дорученням в.о. начальника СВ Київського РВ ХМУ ГУМВС України в Харківській області розпочате досудове розслідування за матеріалами кримінального провадження за ознаками ч. 3 ст. 354 КК України та зазначена попередня кваліфікація - ч. 2 ст. 190 КК України, а також постанова заступника прокурора Київського району м. Харкова ОСОБА_15 про призначення прокурора № 04-36-4464-15 від 17 серпня
2015 р., в якій вказано, що упровадженні СВ Київського РВ ХМУ перебуває кримінальне провадження за ознаками кримінального правопорушення, передбаченого ч. 3 ст. 368 КК України.

У мотивувальній частині виправдального вироку суд першої інстанції зазначив таке: «Ухвала слідчого судді про надання дозволу на проведення НСРД у кримінальному провадженні за ч. 3 ст. 368 КК України, на яку посилається прокурор, не давала підстав для проведення вказаних дій 18 серпня 2015 року у кримінальному провадженні за ч. 3 ст. 354 КК України. Вказана ухвала не зобов'язує, а лише дає дозвіл слідчому в рамках кримінального провадження за ч. 3 ст. 368 КК України проводити вказані дії, після винесення цієї ухвали обов'язок щодо дотримання прав та свобод людини покладено на орган досудового розслідування та прокурора. Передбачені ч. 2 ст. 246 КПК України підстави для проведення НСРД 18 серпня 2015 р. у цьому кримінальному провадженні за ознаками кримінального правопорушенням невеликої тяжкості були відсутні та отримані внаслідок проведення таких дій докази із суттєвим порушенням зазначених норм кримінально-процесуального законодавства, а також прав і свобод людини» [2].

Однією з перших слідчих (розшукових) дій у кримінальних провадженнях про підкуп медичних працівників є допит потерпілого чи викривача.

Предметом такого допиту потерпілого є з'ясування питань: 1) хто є учасником та ініціатором підкупу (надавач неправомірної вигоди, медичний працівник, посередник); 2) місце та час надання (одержання) неправомірної вигоди; 3) предмет і розмір неправомірної вигоди, упаковка, якими купюрами була надана; 4) джерело походження коштів (власні заощадження, позичені - у кого, коли тощо); 5) спосіб надання (одержання) неправомірної вигоди, а також маскування цього 
кримінального правопорушення; 6) чи є свідки надання (одержання) неправомірної вигоди; якщо так, скільки та хто вони; 7) чи є якісь докази, що можуть свідчити про надання (одержання) неправомірної вигоди (для прикладу, матеріали аудіо-, відеозапису, фотографії, інші документи); 8) що відомо про особу одержувача (медичного працівника) або надавача неправомірної вигоди; 9) де, за яких обставин познайомилися учасники події; коли, де, скільки разів зустрічалися раніше; у яких відносинах перебувають; 10) чи мало місце прохання медичного працівника надати йому неправомірну вигоду; 11) за вчинення яких дій було надано (одержано) неправомірну вигоду; 12) інші обставини (для прикладу, чи телефонував хто-небудь до медичного працівника до та після надання (одержання) неправомірної вигоди або заходив до кабінету, де відбувся підкуп, як вони зверталися один до одного тощо).

Якщо допитують викривача, то у нього також необхідно з'ясувати причини та обставини звернення до органів правопорядку, коли та як він дізнався про підкуп медичного працівника, чи він сам був очевидцем події або ж йому повідомила про це інша особа, хто ще може знати про кримінальне правопорушення.

Під час допиту медичного працівника, якому намагалися надати неправомірну вигоду, крім того, належить дізнатися, чи відома йому особа, яка намагалася (намагатиметься) це зробити, як вона виглядає, їі особливі прикмети, хто звертався до нього $з$ проханням вчинити певні дії, але медичний працівник відмовив у цьому, хто з його колег міг бачити цю особу тощо.

Затримання відбувається або після допиту потерпілого чи викривача, коли вони повідомили про те, що у конкретні час та місце готується надання (одержання) неправомірної вигоди, або після того, як неправомірна вигода вже була передана та її предмет знаходиться у медичного працівника, або коли відомо, що медичний працівник систематично одержує неправомірну вигоду у чітко визначений період часу (години прийому).

Варто зазначити, що затримання на початковому етапі розслідування підкупу медичних працівників відбувається у формі тактичної операції, що охоплює допит потерпілого або викривача, спостереження за потенційним правопорушником, його особистий обшук та обшук приміщення, освідування, огляд місця події.

Затриманню медичного працівника передує чимала підготовча робота: з'ясувати точні місце і час надання (одержання) неправомірної вигоди; окреслити її предмет та обробити його спеціальними хімічними засобами, переписати номери купюр, призначених для передання, про що складають протокол огляду, помітки та вручення заздалегідь ідентифікованих засобів; підготувати технічні засоби фіксації, що використовуватимуть під час затримання (фотографування, аудіо-, відеозапис); створити та визначити функції членів слідчо-оперативної групи.

С.В. Олійник обгрунтовано стверджує, що у стадії підготовки до затримання важливо: 1) детально вивчити інформацію, що надійшла від заявника; 2) визначити завдання, що мають бути досягнуті внаслідок затримання; 3) зібрати інформацію про злочинця; 4) вивчити місце затримання; 5) визначитися з учасниками цієї процесуальної дії; 6) детально спланувати їі хід; 7) передбачити та обіграти тактичні ризики [3, с. 161].

Особливо важливо поінформувати потерпілого чи викривача про зміст і порядок процесуальної дії, що проводитиметься. Так, Т.Б. Хачатурян слушно зазначає, що вони мають вести розмову 3 правопорушником так, щоб за іï наслідками можна було зробити висновок про факт надання 
(одержання) неправомірної вигоди (зокрема, уточнити дії, що мають бути вчинені за винагороду, їі розмір тощо). Крім того, їм варто передати кошти у розгорнутому вигляді, схилити правопорушника до їх перерахунку у їхній присутності. Насамкінець, 3 ними варто обумовити сигнал про надання (одержання) неправомірної вигоди, що не викликатиме підозр у правопорушника [4, с. 99-100].

Для здійснення затримання встановлюють оперативне спостереження за ймовірним підозрюваним, обстежують майбутнє місце надання (одержання) неправомірної вигоди ординаторську, маніпуляційну, лабораторію, палату тощо, з'ясовують, у який бік виглядають вікна з цих приміщень, оглядають місця загального користування (туалет, коридор, сходи тощо), що знаходяться поблизу.

Якщо місцем надання (одержання) неправомірної вигоди є громадській простір - парки, сквери, рекомендується так розташувати оперативних працівників, аби запобігти намаганням правопорушника позбутися чи знищити предмет неправомірної вигоди [4, с. 100-101].

Затримання належить здійснити раптово, у момент надання (одержання) неправомірної вигоди або ж відразу після цього. При цьому важливо виключити будь-яку можливість правопорушника викинути, знищити iii предмет або відмовитися від неї (для прикладу, заявити про бажання повернути іiі потерпілому чи викривачу). Для цього рекомендують надати правопорушнику деякий час для вчинення певних дій, що засвідчують прийняття ним неправомірної вигоди [4, с. 103].

Сама тактична операція «затримання на гарячому» полягає у такому. Після отримання сигналу поняті, слідчий, інші члени групи входять до приміщення і пропонують усім особам, які перебувають у ньому, залишатися на своїх місцях. Слідчий пояснює мету прибуття групи і послідовність наступних дій усіх учасників. Одержувачу неправомірної вигоди пропонують відповісти на такі запитання: хто тільки що спілкувався з ним, з якою метою, чи передавав йому що-небудь [4, с. 105].

Після цього необхідно оглянути руки та одяг підозрюваного для виявлення частинок люмінесцентної речовини. На виявлені сліди звертають увагу понятих, роблять змиви 3 рук або зіскоби з одягу i, помістивши їх у відповідну упаковку (поліетиленовий пакет, конверт), опечатують та засвідчують підписами учасників затримання. Потім за допомогою ультрафіолетового освітлювача оглядають приміщення і за розташуванням люмінесцентних слідів виявляють місцезнаходження предмета неправомірної вигоди. При цьому важливо використовувати фотозйомку або відеозапис [4, с. 105-106].

У разі успішного затримання особи на гарячому у слідчого з'являється важливий обвинувальний доказ. Факт затримання стає сильним психологічним чинником, що впливає на поведінку підозрюваного [4, с. 98].

Особистий обшук підозрюваного та обшук за місцем його роботи $i$ проживання доречно проводити відразу після затримання. Їх метою $€$ виявлення та вилучення предмета неправомірної вигоди, а також інших предметів і документів, що мають значення для кримінального провадження (речі, кошти, що раніше могли бути одержані як предмет неправомірної вигоди, записні книжки, щоденники, записи). Саме з огляду на можливість одержання нових доказів, обшуки за місцем роботи і проживання виправдані й тоді, коли предмет неправомірної вигоди вже вилучений. Оперативність у виконанні цих слідчих (розшукових) дій спрямована на запобігання прихованню або знищенню підозрюваним, його друзями, знайомими, членами його сім’ї та родичами доказів. 
Інколи під час обшуку можна виявити не предмет неправомірної вигоди, а лише упаковку, у якій він знаходився під час його отримання. На упаковках можуть зберегтися запис про особу, якій його надали, хто передавав неправомірну вигоду, iii розмір, інші позначки. Також під час цієї слідчої (розшукової) дії доцільно виявляти листи та різні записки, що супроводжували предмет неправомірної вигоди. Слідчому необхідно акцентувати увагу на цих предметах і змісті відповідних написів, що згодом можуть стати об'єктами судових експертиз, призначених у кримінальному провадженні, а також послугувати формулюванню версій [5, с. 118].

У разі необхідності одночасного проведення обшуків у декількох різних місцях необхідно створити групи з оперативних працівників під керівництвом слідчого чи прокурора [6, с. 130].

Як уже неодноразово зазначалося, для затримання правопорушника на гарячому використовують люмінесцентну речовину. Для виявлення слідів цієї речовини на тілі затриманого проводять освідування.

За допомогою джерела ультрафіолетового освітлення спочатку оглядають частини тіла, що не прикриті одягом - руки, обличчя, а потім решту тіла. Виявивши сліди люмінесцентної речовини, роблять змиви з рук (пальців і долонь) підозрюваного. Тампони зі змивами упаковують у поліетиленові пакети 3 наклеєним паперовим написом «Змиви з рук» 3 підписами учасників освідування. Для проведення таких дій доречно залучити спеціаліста.

Згодом за наслідками проведення судово-хімічної експертизи буде визначено наявність або відсутність спільної родової належності люмінесцентної речовини з вилученими зразками.

Основним і обов'язковим засобом фіксації ходу та результатів освідування є протокол, а додатковими засобами є фотографування та відеозапис.
Ще однією слідчою (розшуковою) дією, яку проводять на початковому етапі розслідування підкупу медичних працівників, є огляд місия подї.

Деякі дослідники вважають, що особливості огляду місця події у разі розслідування злочинів, пов'язаних із корупцією, можуть бути зведені до такого:

1) проведення огляду місця події здебільшого здійснюється до внесення інформації до ЄРДР;

2) необхідна точна оцінка ситуації для подальших правильних дій слідчого в ході огляду;

3) огляд місця події дозволяє зібрати і зафіксувати інформацію, що свідчить про вчинення корупційного злочину. Результати огляду дозволяють одержати даніпро кількість осіб,що брали участь у вчиненні злочину, про характер розподілу функцій між ними, ступінь злочинного професіоналізму в діяльності злочинців, характер технічних засобів, використаних для вчинення злочину, про ступінь попередньої продуманості злочинної акції тощо;

4) проведення огляду місця події під час розслідування корупційних злочинів передбачає одержання оперативної інформації, її оцінку і використання в ході слідчих дій [6, с. 120].

Утім не всі з наведених положень є актуальними для розслідування підкупу медичних працівників.

Так, з огляду на окреслені вище слідчі ситуації, що можливі на початковому етапі розслідування цієї категорії кримінальних правопорушень, проведення огляду місця події до внесення відомостей до ЄРДР є недоцільним, не може відбуватися у відриві він інших процесуальних дій цього етапу, що виконують у межах спланованої тактичної операції. Крім того, відомості про місце, час, обстановку, учасників та інші обставини підкупу медичних працівників слідчий одержує задовго до проведення огляду місця події у такому кримінальному провадженні. 
Огляд місця події на початковому етапі розслідування підкупу медичних працівників здійснюють 3 метою вивчення обстановки, за якої відбувалося надання (одержання) неправомірної вигоди, виявлення слідів кримінального правопорушення та інших доказів. Зокрема, сліди люмінесцентної речовини найчастіше можуть бути виявлені на робочому столі медичного працівника, його смартфоні, комп'ютері чи ноутбуку, медичній документації, кошику для сміття, шафі з документацією.

Якщо предмет неправомірної вигоди виявлено під столом, необхідно визначити, під якою конкретно його частиною та на якій відстані від місць розміщувалися потерпілий чи викривач та правопорушник. У такий спосіб фіксують положення цього об'єкта, знайденого між паперів або у сейфі; вимірюють відстань від нього до точок, у яких перебували зазначені суб'єкти. Подеколи рекомендують провести вимірювання стільниці столу та його відділень, осередків сейфів, у яких було виявлено передані цінності, відстань від них до меж об'єктів, що оглядають. У разі виявлення предмета неправомірної вигоди серед ділових паперів, документів, що лежать на столі, у сейфі правопорушника, потрібно зосередити увагу на тому, як скріплено документи. Виявлення предмета неправомірної вигоди серед підшитих, скріплених у спеціальних папках документів потребує пояснення та з'ясування можливості його самостійної закладки потерпілим чи викривачем [5, с. 96-97].

У разі виявлення об'єктів огляду слідчому належить запитати у медичного працівника, як вони опинилися у нього.

Обстановка місця події та сліди підкупу медичного працівника повинні бути детально зафіксовані у протоколі, схемах, у матеріалах фото- та відеозапису.
Окремо доречно зупинитися на виборі понятих. Не варто залучати до участі у проведенні огляду місця події понятих 3 числа персоналу медичного закладу, аби виключити можливість впливу на них затриманого медичного працівника.

Огляд місця події в аналізованій категорії кримінальних правопорушень проводять за місцем затримання правопорушника на гарячому. Таким місцем може бути приміщення закладу охорони здоров'я, у якому працює чи прийшов за наданням медичної допомоги чи одержанням медичних послуг правопорушник, інше володіння правопорушника, потерпілого, викривача (транспортний засіб), публічний простір (парки, сквери, кафе).

Для прикладу, в одному з кримінальних проваджень, маючи достовірну інформацію про незаконне зберігання предмета неправомірної вигоди у приміщенні моргу КЗ «Криворізька інфекційна лікарня № 1», отриманих медичним працівником ОСОБА_2 від ОСОБА 5, з метою недопущення їх знищення, втрати або реалізації було проведено огляд приміщення моргу, за наслідками якого у ОСОБА_2 вилучені кошти в сумі 800 грн, які їй передала ОСОБА_5 [7].

Проте у правозастосовній практиці трапляються випадки, коли огляд місця події проводять у приміщенні органу досудового розслідування.

Так, неправомірна вигода, запропонована та надана медичному працівнику ОСОБА_2 у розмірі 1600 грн, вилучена працівниками поліції під час огляду місця події у приміщенні кабінету прийому громадян Новопсковського ВП ГУНП у Луганській області за адресою: вул. Слобожанська, 20, смт Новопсков Луганської області [8].

Як видається, в описаному випадку у приміщенні органу досудового розслідування проводився не огляд місця події, а огляд потерпілого, за наслідками 
якого і було виявлено та вилучено предмет неправомірної вигоди.

Допит підозрюваного проводять одразу ж після його затримання на місці вчинення кримінального правопорушення. Метою допиту є встановлення всіх обставин підготовки, вчинення та приховування підкупу медичного працівника. На першому допиті підозрюваного основна увага звертається на встановлення якомога більшого числа деталей надання (отримання) неправомірної вигоди і докладне з'ясування тих дій, які він повинен був виконати, 3 ким був пов'язаний, як мав намір діяти. 3'ясовують коло його службових обов'язків, порядок роботи медичного закладу, в якому він працює.

Предметом допиту підозрюваного є: 1) відомості про його особу; 2) посадові обов'язки та документи, що їх підтверджують (статут чи інші установчі документи медичного закладу; накази, посадові інструкції тощо); 3) характер взаємин підозрюваного та потерпілого; 4) предмет неправомірної вигоди та його розмір; 5) обставини надання (одержання) неправомірної вигоди; 6) дії, які вчинені в інтересах надавача неправомірної вигоди; 7) можливі свідки надання (одержання) неправомірної вигоди; 8) обставини затримання.

У безконфліктній ситуації допит підозрюваного проводять 3 використанням таких тактичних прийомів, як: звернення до його позитивних рис характеру; поінформованість слідчого про особисте життя підозрюваного; використання асоціативних зв'язків, деталізація показань.

Під час допиту у конфліктній ситуації підозрюваний у підкупу медичного працівника може стверджувати, що: 1) мав місце факт провокації підкупу; 2) предмет неправомірної вигоди йому залишили чи підкинули, але він його не торкався; 3) відсутні підстави для проведення щодо нього процесуальних дій; 4) відсутній умисел у наданні (отриманні) неправомірної вигоди; 5) отримав не неправомірну вигоду, а подарунок; 6) відбулося повернення йому боргу або ж сам взяв у борг; 7) предмет неправомірної вигоди залишили йому на тимчасове зберігання; 8) взяв кошти за надання послуг, не пов’язаних зі здійсненням ним професійної діяльності (для прикладу, за посередництво у купівлі-продажу нерухомості, автомобіля); 9) здійснене ним за винагороду діяння виходить за межі його службових обов’язків; 10) процесуальні дії проведені з істотним порушенням закону, їх результати є недійсними, а одержані докази - недопустимими.

Так, підозрюваний ОСОБА 4 винуватим себе у вчиненні вказаного кримінального правопорушення, передбаченого ч. 3 ст. 354 КК України, не визнав, пояснивши, що ніякої неправомірної вигоди не отримував, 2500 грн йому ОСОБА 2 не давав, a 7500 грн ОСОБА_2 був йому винний за невиконані висотні роботи 3 утеплення квартири, та віддав 3 них 6000 грн [2].

В аналізованій ситуації слідчий використовує такі тактичні прийоми допиту, як: пред'явлення доказів, створення у підозрюваного враження про свою поінформованість; метод непрямого допиту.

Коли ж підозрюваний відмовився давати показання, слідчому належить роз'яснити йому переваги у даванні повних і правдивих показань, продемонструвати свою обізнаність у деталях події кримінального правопорушення, повідомити про намір провести низку процесуальних дій, спрямованих на збирання доказів.

Огляд документів спрямований на встановлення законності та правильності оформлення вчиненої медичним працівником дії, з'ясування того, чи належить видання такого документа до посадових обов'язків цього медичного працівника, чи не вийшов він при цьому поза межі 
наданих йому повноважень. Огляд документів дає можливість з'ясувати, чи була отримана неправомірна вигода за надання медичної допомоги або за одержання медичної послуги позачергово. Для цього необхідно звернути увагу на дату складання документа та порівняти період прийняття рішення зі строком вирішення цього ж питання для інших осіб [4, с. 94].

Огляд документа полягає у вивченні змісту інформації, що у ньому викладена, у з'ясуванні відповідності цієї інформації іншим доказам у кримінальному провадженні, іiі узгодженості із законодавчими та підзаконними нормативно-правовими актами.

До документів, про які йдеться, належать: статут або інші установчі документи медичного закладу, ліценція на здійснення медичної практики, графік роботи медичного закладу, перелік видів медичної допомоги і медичних послуг, що надаються, правила надання медичної допомоги і медичних послуг, прейскурант цін, договори про надання медичних послуг, формуляри інформованих згод пацієнта на певні види медичних втручань, формуляри відмови пацієнта від медичного втручання, акти про відмову пацієнта від медичного втручання, книга заяв і пропозицій, стандарти якості надання медичної допомоги, положення про контроль якості надання медичної допомоги, штатний розпис, документація по роботі з кадрами, посадові інструкції, правила внутрішнього трудового розпорядку, графік відпусток, положення про преміювання працівників медичного закладу, паспорт підозрюваного, свідоцтво про шлюб, свідоцтво про народження дітей, його особисті записи.

Допит свіджів. Свідками аналізованої категорії кримінальних правопорушень можуть бути члени сім'і, близькі родичі, друзі, знайомі потерпілого або викривача, підозрюваного, медичний персонал.
Під час допиту свідків підкупу медичного працівника необхідно з'ясувати: 1) обставини безпосереднього надання (отримання) неправомірної вигоди; 2) відомості про предмет неправомірної вигоди; 3) обставини, що характеризують потерпілого і підозрюваного, його відносини з ними; 4) відомості про інших осіб, які можуть бути поінформовані про факт підкупу медичного працівника.

Свідки, які є членами сім'ї або близькими родичами підозрюваного, на підставі ч. 1 ст. 63 Конституції України, ст. 18 КПК України вправі відмовитися від давання показань, якщо вони стосуються підозри у вчиненні кримінального правопорушення їх близькими родичами чи членами їх сім’ї. 3 іншого боку, не варто виключати й випадки давання такими свідками завідомо неправдивих показань. Тоді слідчий повинен здійснювати 3 ними процесуальне спілкування в умовах конфліктної ситуації з використанням відповідних тактичних прийомів допиту.

Вищевикладене дає можливість сформулювати такі висновки. На початковому етапі розслідування підкупу медичних працівників проводять такі процесуальні дії, як: 1) допит потерпілого або заявника (викривача); 2) огляд майбутнього предмета неправомірної вигоди; 3) затримання правопорушника на гарячому і тимчасове вилучення майна; 4) особистий обшук підозрюваного, а за необхідності - його освідування; 5) огляд місця події; 6) допит підозрюваного; 7) обшук за місцем роботи та проживання підозрюваного, а за наявності для цього підстав - у родичів, друзів, знайомих; 8) огляд документів, що регламентують діяльність медичного закладу (статут, інші установчі документи), та визначення кола службових обов'язків медичного працівника (посадові інструкції, накази); 9) допит свідків. 
У кримінальних провадженнях, розпочатих за ч. 4 ст. ст. $368^{3}, 368^{4} \mathrm{KK}$ України (належать до категорії тяжких), на початковому етапі розслідування підкупу медичних працівників передбачена легальна можливість проводити негласні слідчі (розшукові) дії. У інших кримінальних правопорушеннях про підкуп медичних працівників (ст. 354, чч. 1-3 ст. $368^{3}$, чч. 1-3 ст. $368^{4}$ КК України) можуть бути проведені лише такі негласні слідчі (розшукові) дії, як зняття інформації з електронних інформаційних систем або їх частин, доступ до яких не обмежується іiі власником, володільцем або утримувачем чи не пов'язаний з подоланням системи логічного захисту, установлення місцезнаходження радіоелектронного засобу.

До процесуальних дій, які логічно слідують за вищевизначеними і проводять нанаступному етапі розслідування підкупу медичних працівників, належать накладення арешту на майно та призначення і проведення експертизи.

\section{Список використаних джерел}

1. Чернявський С.С. Особливості розслідування одержання пропозиції, обіцянки або одержання неправомірної вигоди посадовою особою. Вісник кримінального судочинства. 2015. № 1. С. 223-229.

2. Вирок Ленінського районного суду м. Харкова від 30 березня 2017 р. (справа № 642/8876/15к; провадження № 1-кп/642/19/17). URL: https://reyestr.court.gov.ua/ Review/65666598.

3. Олійник С.В. Початковий етап та основні напрями розслідування прийняття пропозиції, обіцянки або одержання неправомірної вигоди службовою особою : дис. ... канд. орид. наук : 12.00 .09 «Кримінальний процес та криміналістика; судова експертиза; оперативно-розшукова діяльність». Відкритий міжнародний університет розвитку людини «Україна». Київ, 2016. 220 с.

4. Хачатурян Т.Б. Выявление и расследование взяточничества в органах исполнительной власти : дисс. ... канд. юрид. наук : 12.00.09. «Уголовный процесс; криминалистика и судебная экспертиза; оперативно-розыскная деятельность». Академия информационных технологий в образовании, науке и курортологии. Волгоград, 2004. 212 с.

5. Андрейко Ю.О. Проведення слідчих (розшукових) дій під час розслідування одержання неправомірної вигоди службовою особою : дис. ... канд. юрид. наук : 12.00 .09 «Кримінальний процес та криміналістика; судова експертиза; оперативно-розшукова діяльність». Національна академія внутрішніх справ. Київ, 2020. 283 с.

6. Кимлик Н.В., Кимлик Р.В., Жерж Н.А. Розслідування корупційних правопорушень в кримінальному процесі України : монографія. Ірпінь : Національний університет ДПС України, 2014. 226 с.

7. Вирок Дзержинського районного суду м. Кривого Рогу Дніпропетровської області від 24 листопада 2017 р. (справа № 210/909/17; провадження № 1-кп/210/271/17). URL: https://reyestr.court.gov.ua/Review/70468822.

8. Вирок Новопсковського районного суду Луганської області від 27 березня 2018 р. (справа № № 420/283/18; провадження №1-кп/420/87/18). URL: https://reyestr.court.gov.ua/Review/72982785.

Фігурський В. М., Юрків Р. Р. Процесуальні дії початкового етапу розслідування підкупу медичних працівників

Стаття присвячена характеристиці процесуальних дій початкового етапу розслідування підкупу медичних працівників.

Визначено, що на початковому етапі розслідування підкупу медичних працівників проводять такі процесуальні дії, як: 1) допит потерпілого аббо заявника (викривача); 2) огляд майбутнього предмета неправомірної вигоди; 3) затримання правопорушника 
на гарячому і тимчасове вилучення майна; 4) особистий обшук підозрюваного, а за необхідності - його освідування; 5) огляд місця події; 6) допит підозрюваного; 7) обшук за місцем роботи та проживання підозрюваного, а за наявності для цього підстав - у родичів, друзів, знайомих; 8) огляд документів, що регламентують діяльність медичного закладу (статут, інші установчі документи), та визначення кола службових обов'язків медичного працівника (посадові інструкції, накази); 9) допит свідків.

Констатовано, що у кримінальних провадженнях, розпочатих за ч. 4 ст. ст. $368^{3}, 368^{4}$ КК України (належать до категорії тяжких), на початковому етапі розслідування підкупу медичних працівників передбачена легальна можливість проводити негласні слідчі (розшукові) дії. У інших кримінальних правопорушеннях про підкуп медичних працівників (ст. 354 , ч.ч. $1-3$ ст. $368^{3}$, ч.ч. 1-3 ст. $368^{4}$ КК України) можуть бути проведені лише такі негласні слідчі (розшукові) дії, як зняття інформації з електронних інформаційних систем або їх частин, доступ до яких не обмежується ії̈ власником, володільцем або утримувачем чи не пов'язаний з подоланням системи логічного захисту, установлення місцезнаходження радіоелектронного засобу.

Зазначено, що однією з перших слідчих (розшукових) дій у кримінальних провадженнях про підкуп медичних працівників є допит потерпілого чи викривача.

Обгрунтовано, що затримання на початковому етапі розслідування підкупу медичних працівників відбувається у формі тактичної операції, яка охоплює допит потерпілого або викривача, спостереження за потенційним правопорушником, його особистий обшук та обшук приміщення, освідування, огляд місця події.

Ключові слова: підкуп, неправомірна вигода, медичні працівники, початковий етап розслідування, процесуальні дії.

Фигурский В. М., Юркив Р. Р. Процессуальные действия первоначального этапа расследования подкупа медицинских работников

Статья посвящена характеристике процессуальных действий начального этапа расследования подкупа медицинских работников.

Определено, что на начальном этапе расследования подкупа медицинских работников проводят такие процессуальные действия, как: 1) допрос потерпевшего или заявителя; 2) осмотр будущего предмета неправомерной выгоды; 3) задержание правонарушителя с поличным и временное изъятие имущества; 4) личный обыск подозреваемого, а при необходимости - его освидетельствование; 5) осмотр места происшествия; 6) допрос подозреваемого; 7) обыск по месту работы и жительства подозреваемого, а при наличии для этого оснований - у родственников, друзей, знакомых; 8) осмотр документов, регламентирующих деятельность медицинского учреждения (устав, другие учредительные документы), и определение круга служебных обязанностей медицинского работника (должностные инструкции, приказы); 9) допрос свидетелей.

Констатировано, что в уголовных процессах, начатых по ч. 4 ст. $368^{3}, 368^{4}$ УК Украины (относятся к категории тяжких), на начальном этапе расследования подкупа медицинских работников предусмотрена легальная возможность проводить негласные следственные (розыскные) действия. В других уголовных правонарушениях о подкупе медицинских работников (ст. 354, ч.ч. 1-3 ст. $368^{3}$, ч.ч. 1-3 ст. $368^{4}$ УК Украины) могут быть проведены только такие негласные следственные (розыскные) действия, как снятие информации с электронных информационных систем или их частей, доступ к которым не ограничивается ее собственником, владельцем или держателем, и не связан с преодолением системы логической защиты, установления местонахождения радиоэлектронного средства.

Отмечено, что одним из первых следственных (розыскных) действий по уголовным делам о подкупе медицинских работников является допрос потерпевшего или заявителя.

Обосновано, что задержание на начальном этапе расследования подкупа медицинских работников происходит в форме тактической операции, которая охватывает допрос 
потерпевшего или заявителя, наблюдение за потенциальным правонарушителем, его личный обыск и обыск помещения, освидетельствование, осмотр места происшествия.

Ключевые слова: подкуп, неправомерная выгода, медицинские работники, начальный этап расследования, процессуальные действия.

Fihurskyy V., Yurkiv R. Procedural actions of the initial stage of the investigation of medical workers bribery

The article is devoted to the characteristics of the procedural actions of the initial stage of the investigation of medical workers bribery.

It is determined that at the initial stage of the investigation of medical workers bribery the following procedural actions are carried out: 1) interrogation of the victim or the applicant; 2) review of the future subject of illicit gain; 3) detention of the offender on hot and temporary seizure of property; 4) personal search of the suspect, and if necessary - his examination; 5) inspection of the scene; 6 ) interrogation of the suspect; 7) search at the place of work and residence of the suspect, and if there are grounds for this - relatives, friends, acquaintances; 8) review of documents regulating the activities of the medical institution (charter, other constituent documents) and determine the scope of duties of the medical worker (job descriptions, orders); 9) interrogation of witnesses.

It is stated that in criminal proceedings initiated under Part 4 of Art. $368^{3}, 368^{4}$ of the Criminal Code of Ukraine (belong to the category of serious), at the initial stage of the investigation of bribery of medical workers, there is a legal opportunity to conduct covert investigative (search) actions. In other criminal offenses of bribery of medical workers (Article 354, parts 1-3 of Article $368^{3}$, parts 1-3 of Article $368^{4}$ of the Criminal Code of Ukraine), only such covert investigative (search) actions as removal of information from electronic information systems or their parts, access to which is not limited by its owner, possessor or holder or is not related to overcoming the system of logical protection, locating the electronic means.

It is noted that one of the first investigative (search) actions in criminal proceedings on bribery of medical workers is the interrogation of the victim or applicant.

It is substantiated that the detention at the initial stage of the investigation of medical workers bribery takes the form of a tactical operation, which includes interrogation of the victim or applicant, observation of a potential offender, his personal search and search of premises, inspection, scene inspection.

Key words: bribery, illicit gain, medical workers, initial stage of investigation, procedural actions. 